\title{
Short Review of Health care activities in Sierra Leone during UN peace keeping mission
}

\author{
Major Kamala Subba \\ Nursing Department \\ Shree Birendra Hospital
}

On be- half of my team mates, I would like to give a brief experience of my seven months of health care activities during our peace keeping mission in Sierra Leone October 2001-May 2002. After a long waiting I got this noble opportunity to serve as a medical sister nurse along with our NEP BATT 1 in Sierra Leone.

Since Nepal is famous for it's bravery, which has been proved out in different way in different time, once again Nepal got an opportunity to prove of what it is famous for Like in Lebanon (UNIFIL), UNGCL (United nation guard contingent in Iraq), UNITED NATION OPERATION IN SOMALIA, UNITED MISSION IN HAITI. Sierra Leone is the mission, which has been handed to Nepal by UN along with other countries like Bangladesh, Pakistan \& Ghana.

This mission is particularly first time mission to Nepal. Beside other mission Nepal accepted it without any hesitation. In the mid of sept.2001 Infantry unit Devi Datta Gana moved to Sierra Leone with 46 officers \& rest of other ranks JCOS, NCOS under command of Lt. Col. Victor JBR.

\section{Brief introduction of Sierra Leone}

Sierra Leone, which has also a long name "REPUBLIC OF Sierra Leone" It, is located in the western part of Africa boarding the North Atlantic Ocean between guinea \& Liberia. Capital city is free town it has an area of 71740 Square KM, land $71620 \mathrm{sq} . \mathrm{km}$, water $120 \mathrm{sq}$. km. which is comparatively slightly smaller than Nepal. Its climate is tropical; hot, humid; summer rainy season (May to Dec); winter dry season (DEC-April). Natural resources are diamonds, titanium ore, bauxite ore, gold, and chromate.

Natural hazards are dry, sand-laden harmattan winds blow from the sahara (December to February); sandstorms, dust storms. Current environmental issue is rapid population growth pressuring in the environment over harvesting of timber, expansion of cattle grazing, Slash \& burn Agriculture have been resulted in deforestation, soil exhaustion, civil war depleting natural resources, over fishing. Besides being a small country it has a population of 5,426,618 EST in July 2001 . Population growth rate $3.61 \%$, infant mortality rate is 146.52 deaths $/ 1,000$ live births, HIV/AIDS adult prevalence rate $2.99 \%$. Life expectancy is 45.6 years. Main religions are Muslim 60\%, indigenous beliefs 30\% \& Christian $10 \%$.

\section{Medical activities}

Our medical team was consists of 22 members ( 2 medical officer, 2 officer sister, 2 JCO sister rest of others were JCOs \& NCOs). Level I hospital was established in MOYAMBA HQ \& other posts were located at different places like Alpha coy in Bonthe, B Coy in Rotefung, C\& D coy were attached in HQ, \& E coy in Gbanbatok. 
When NEP BATT deployed, most of the parts of the Sierra Leone was deadly destructed due to ci war. There was no any single house without bullet hole, there were no roofs, villages were covered with thick bushes like forest. In such situation we had to construct shelter own self. Our shoulders were stayi in tent. We have not only to bring peace but also have to fight with diseases, incidence like snakebite accidents etc.

This place was epidemic zone for Malaria (severe type of P.falciparum). Our medical assistants w deployed in each post with first aid treatment and some medicine. Our main Job was to provide first? treatment, prevent the disease from spreading, maintaining hygiene and sanitation, making our sold awareness against HIV /AIDS and other diseases.

Our next challenge was snakebite. We did not have sufficient anti snake Venom we told all personal hi to protect themselves form Snake bite \& Malaria etc. Luckily we did not dad any snakebite cases.

\section{Malaria:}

Since the malaria was the main disease we had to suffer and treat in that particular mission, I would $\mathrm{l}$ explain the situation here. "Malaria is a protozoal disease caused by infection with parasites of the get plasmodium \& transmitted to men by certain species of infected female Anopheline mosquito.

\section{Prevention and treatment:}

Malaria prophylaxis was given to whole troop: tab. Mafloquine $250 \mathrm{mg}$ once a week regularly which $v$ started before we depart from Nepal.

Following drugs were prescribed for malaria treatment according to their sensitivity

1. Tab. chloroquine $150 \mathrm{mg} 4$ tabs, stat then 2 tab. after 6 hour.

Next day 1 tab. BD for 2 days.

or

2. Tab. Quinine 300mg 2 tab 3 times 7 days.

or

3. Tab. Artisunate $50 \mathrm{mg} 2$ tab stat $\&$ then 1 tab twice a day for 5 days.

or

4. Inj. quinine $300 \mathrm{mg}$ over 4 hours with $5 \%$ dextrose till fever comes under control 8 hourly.

Sufficient I.V. drips $5 \%$ dextrose \& oral plenty of glucose water was given to control hypoglycer and dehydration.

\section{Badical treatment}

Above regimen followed by

1. Tab. Premaquine $15 \mathrm{mg} 1$ tab twice a day for 14 days.

or

2. Tab. Sulfadoxine-Pyrimethamine (fansider) 3 tab single dose.

Complication: Generally the complication of p.falciparum malaria are cerebral malaria, ac renal failure liver damage, gastrointestinal symptoms, dehydrations \& anemia, spleeno-megi enlargement of liver, herpes, renal complications (from P.vivex, P.ovale \& malarae). Out of: cases, no one had got severe type of complication. Out of 800 person 364 were suffered fo Malaria most of them were falciparum Malaria. 


\section{Incident of Malaria to RNA in Sierra Leone}

From Sept.2001-may 2002

$\begin{array}{ll}\begin{array}{l}\text { Total person } \\ \text { Total infected }\end{array} & 800 \\ & 364 \\ \text { Infected once } & 281 \\ \text { Relapse cases } & 58 \text { (Second Time) } \\ \text { Relapse cases } & 22 \text { (Third Time) } \\ \text { Relapse cases } & 3 \text { (Fourth Time) }\end{array}$

Type of Malaria according to lab finding.

$\begin{array}{llll}\text { A. } & \text { P.Falcipanum } & 199 & \text { cases } \\ \text { B. } & \text { P.Vivex } & 37 & \text { cases } \\ \text { C. } & \text { Mixed P.V.+ PV } & 16 & \text { cases } \\ \text { D. P. Malaria } & 1 & \text { cases } \\ \text { E. P. U.O. (Fever) } & 18 & \text { cases } \\ \text { F. Non classified Malaria } & 93 & \text { cases }\end{array}$

Skin problem was also the second common problem.

Health care was not only provided within us but also to local people. Considering their needs once of week we run health care service and the provided them very essential medicines, school health services provided along with medicines and food. Health check-up and medicine given to orphanage home and to the prisoners. Often we visited to different villages with medicines and the some food stuffs. So these facts shows nursing care is not only limited to the hospitals but also it is important in different parts of community coordinating with different people, fact finding, planning $\&$ implementing them within a limited resources were really impressive

Within very short duration NEPBATT 1 medical team received remarkable impression from force headquarter as well as in Sierra Leon Moyamba. Keeping the spirit, helping nature bravery RNA be always in front line to serve human kind.

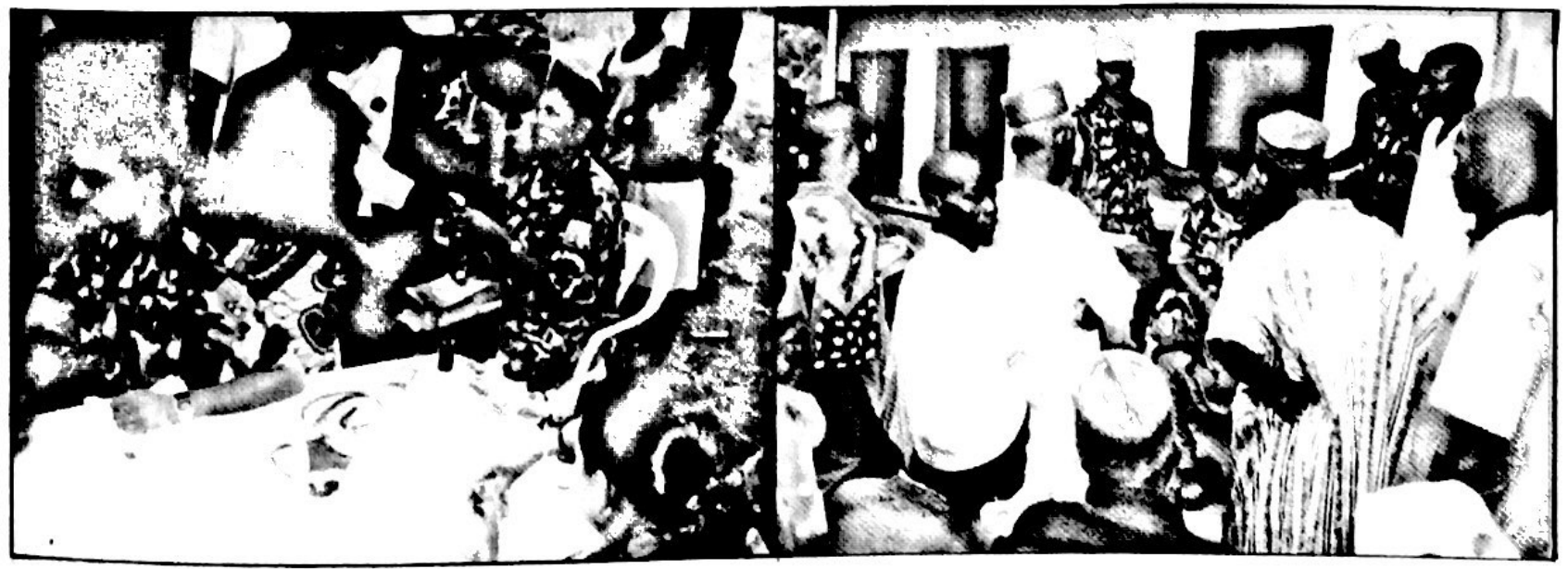

